\title{
Effect of Lablab Bean (Lablab purpureus L.) Seed Flour on the Physicochemical and Sensory Properties of Biscuits
}

\author{
Rahmatuzzaman Rana ${ }^{1, *}$ A. S. M. Sayem, Ashfak Ahmed Sabuz ${ }^{2}$ Towhidur Rahman ${ }^{3}$, Abrar Hos- \\ $\operatorname{sain}^{1}$ \\ ${ }^{1}$ Department of Food Engineering and Tea Technology, Shahjalal University of Science and Technology, Sylhet-3114, Bangla- \\ desh. \\ ${ }^{2}$ Postharvest Technology Division, Bangladesh Agricultural Research Institute, Gazipur, Bangladesh. \\ ${ }^{3}$ Upazila Nirbahi Officer (Chief Administrative Officer of a Sub-District), Fulbari, Kurigram, Bangladesh.
}

\begin{abstract}
How to cite this paper: Rahmatuzzaman Rana, A. S. M. Sayem, Ashfak Ahmed Sabuz, Towhidur Rahman, Abrar Hossain. (2021) Effect of Lablab Bean (Lablab purpureus L.) Seed Flour on the Physicochemical and Sensory Properties of Biscuits. International Journal of the Science of Food and Agriculture, 5(1), 52-57. DOI: 10.26855/ijfsa.2021.03.008
\end{abstract}

Received: December 20, 2020

Accepted: January 15, 2021

Published: January 27, 2021

*Corresponding author: Rahmatuzzaman Rana, Department of Food Engineering and Tea Technology, Shahjalal University of Science and Technology, Sylhet-3114, Bangladesh.

Email: rzaman-fet@sust.edu

\begin{abstract}
Lablab bean (Lablab purpureus L.) seeds have characterized for usage a protein supplement in bakery items. In order to prepare biscuits 0, 5, 10, 15 and 20\% lablab bean seed powder blended with wheat flour. The flours were tested for their chemical composition. Lablab bean seed flour had high protein (23.2\%), ash (3.1\%) and dietary fiber (1.8\%) content, and low in fat (1.2\%) and carbohydrates (59.74\%). The spread ratio reduced as bean seed flour was incorporated. The protein, crude fiber and ash content of biscuits significantly enhanced $(p \leq 0.05)$ with addition of lablab bean seed flour. When wheat flour replaced with lablab seed flour up to $10 \%$, the sensory properties (overall score above 7) of composite flour biscuits were more or less identical to the control biscuits. Therefore, the lablab bean seed flour can enrich biscuits with the blending of wheat/lablab bean seed flour.
\end{abstract}

\section{Keywords}

Lablab Bean Seed Flour, Supplemented Biscuits, Physicochemical Properties, Sensory Quality

\section{Introduction}

Protein deficiency in human nutrition is well known in Bangladesh for its cereal-based dietary pattern and other underdeveloped countries where animal proteins are insufficient [1, 2]. Many studies are underway to increase conventional protein diets by choosing alternative protein sources such as vegetables or other origins. Legumes (Leguminosae or Fabaceae) are good sources of vegetable protein, which are affordable and almost complete in essential amino acids $[3,4]$.

Lablab bean, Lablab purpureus (L.); previously termed as Dolichos lablab L., belongs to the family leguminous (Fabaceae), which draws attention to the researcher of its seeds and pods contain $20 \%-28 \%$ protein. This is believed to be originated in India and commonly known as hyacinth bean, Sim bean, Tonga bean, Val bean, horse bean 'Indian butter bean', 'Egyptian kidney bean' [5, 6]. Lablab beans are a good source for carbohydrates, proteins, essential amino acids, fatty acids, fibers, bioactive and mineral components [2]. Despite their health advantages, lablab bean does have anti-nutritional effects, which can influence protein and certain minerals, as well as phytic acid, trypsin, saponin and tannins [7]. Conventional processing methods such as removing seed coat, frying, sprouting, and fermentation are successful in mitigating anti-nutritional factors [8]. The dry bean seeds are often used to prepare several foods like spicy curries, dahl, and boiled and mashed with the banana to make sweet dishes in Southeast Asian countries. Dried beans 
are used in households, restaurants, food processing industries [9]. In recent years, the choice of vegetarianism draws attention to the researcher, because the dry beans are denser than cereals nutrients and accordingly, their functional properties have often been studied to enhance the use and recognize the interactions of processing parameters [10]. The dry bean seed flour can be used in bakery products [11].

Bakery products, particularly biscuits, are immensely popular because of their versatility, such as longer storage, wider consumption, different texture and taste [12]. So, flours from indigenous legumes like lablab bean seed flour with high protein content could be used to replace part of wheat flour to produce protein-enriched biscuit to satisfy functional characteristics and nutrients composition, and as well as reduce wheat importation and support food diversification and security. Therefore, this study aims to determine the proximate composition, physicochemical properties, and sensory analysis of composite flour biscuits.

\section{Methods}

The experiment was carried out in the Department of Food Engineering and Tea Technology, Shahjalal University of Science and Technology, Sylhet, Bangladesh.

\subsection{Raw Materials}

Lablab bean (Lablab purpureus L.), BARI Seam 1 dry seeds were collected from Bangladesh Agricultural Research Institute (BARI), Gazipur. Visually discolored, diseased, damaged samples were removed to minimize biological variability. All other ingredients were collected from the local market.

\subsection{Flour preparation}

The whole dry bean seed (including seed coat) was ground to produce homogeneous flours in a heavy grinder (IKA M 20, Universal Mill, Germany). The flours were sieved through a 80 ASTM $(200 \mu \mathrm{m})$ sieve and stored in high-density polyethene bag at $-20^{\circ} \mathrm{C}$ until further use.

\subsection{Biscuit preparation}

Wheat flour was substituted in four quantities 5, 10, 15, and 20\% with dry bean seed flour (BSF) and designed in T1, T2, T3 and T4 respectively, where BSF was not supplemented, served as control $\mathrm{T}_{\mathrm{o}}$. Table 1 illustrates the basic formulations used to prepare biscuits. The dough has been prepared for biscuit following AACC 10-54 with some adjustments [13]. All dry ingredients were mixed, chemicals and sugar were dissolved in water, and all were thoroughly mixed with a mixer (WMIX-KF13, Walton, Bangladesh). The dough was relaxed for 15 minutes and rolled out and cut to discs with a diameter of $5.5 \mathrm{~cm}$ and $3 \mathrm{~mm}$. The cut-out biscuits were put around 0.5 inches apart on either greased pans, and the biscuits were remained in the pan for around $10 \mathrm{~min}$, baked at $180^{\circ} \mathrm{C}$ for $10-15 \mathrm{~min}$ till baked, cooled to room temperature and sealed into airtight high-density polyethene packets.

Table 1. Formulation of biscuits with mixture of what and bean seed flour

\begin{tabular}{|c|c|c|c|c|c|}
\hline \multirow{2}{*}{ Ingredients } & \multicolumn{5}{|c|}{ Quantity (g/100 g) } \\
\hline & Control & $\mathbf{T 1}$ & $\mathbf{T 2}$ & T3 & T4 \\
\hline Wheat flour & 100 & 95 & 90 & 85 & 80 \\
\hline Bean seed flour & -- & 5 & 10 & 15 & 20 \\
\hline Vegetable oil & 40 & 40 & 40 & 40 & 40 \\
\hline Sucrose & 40 & 40 & 40 & 40 & 40 \\
\hline Sodium-chloride & 0.5 & 0.5 & 0.5 & 0.5 & 0.5 \\
\hline Powder milk & 5 & 5 & 5 & 5 & 5 \\
\hline Baking powder & 5 & 5 & 5 & 5 & 5 \\
\hline Water & 20 & 20 & 20 & 20 & 20 \\
\hline
\end{tabular}

\subsection{Proximate analysis}

Prepared bean seed flour and biscuits were analyzed for moisture, protein (micro-Kjeldahl, $\mathrm{N} \times 6.25$ ), fat (solvent extraction), crude fiber and ash were determined according to method described in AOAC (2010) [14]. The carbohydrate content was calculated by subtraction method. 


\subsection{Evaluation of physical properties of biscuits}

The biscuits weight was calculated as a mean of three single biscuits with a digital balance meter. The biscuit diameter was calculated by putting three biscuit edge to edge horizontally in a row, and a vernier Caliper used to measure the diameter $(\mathrm{cm})$ with an average value of $0.01 \mathrm{~mm}$ accuracy. Thickness was determined after three biscuits were placed on each other, and the mean thickness $(\mathrm{cm})$ was taken into consideration. The spread ratio was determined by comparing the mean diameter with mean thickness of the biscuit.

\subsection{Sensory evaluation}

The sensory evaluation of biscuits was conducted by 15 semi-trained testers who frequently consumed biscuits and were experienced with the sensory quality attributes of biscuits. The test was performed using 09-point hedonic numbering from 1 (disliked extremely) to 9 (liked extremely). Three-digit random numbers have been encoded and displayed in identical containers. Every sample was rated for color, texture, flavor, and overall acceptability.

\subsection{Statistical analysis}

A one-way variance analysis (ANOVA) was performed on the triplicate data using SPSS software (SPSS version 15.0 SPSS Inc. Chicago, Illinois, U.S.A). All values were represented as a percentage and mean \pm SD, and statistically significant differences among samples were determined with DMRT test at $\mathrm{p}<0.05$ consideration.

\section{Results and discussion}

\subsection{Proximate composition lablab bean seed flour}

The proximate composition of wheat flour and dry lablab bean seed flour (BSF) is shown in Table 2. According to the analysis, like wheat flour carbohydrate was the dominant part of the lablab bean seed flour, accounting for about $59.74 \pm 0.09 \%$, followed by protein and moisture with $23.2 \pm 0.22 \%$, and $10.96 \pm 0.18 \%$, respectively. These observations are in agreement with other studies $[2,15]$. The higher amount of protein in seed flour may provide a prominent solution to malnutrition problems by incorporating several baked products. In dry bean seed flour, the ash content was $3.1 \pm 0.03$, higher than wheat flour and signifies more maco- and micro-nutrients. Owing to the disparity in the flour samples' carbohydrate content, the variation can be ascribed to differences in other materials.

Table 2. Composition of a fresh bean seed and bean seed powder

\begin{tabular}{ccc}
\hline Parameters & Dry bean seed powder $(\mathrm{g} / 100 \mathrm{~g})^{\mathrm{a}}$ & ${\text { Wheat flour }(\mathrm{g} / 100 \mathrm{~g})^{\mathrm{a}}}^{\mathrm{a}}$ \\
\hline Moisture & $10.96 \pm 0.18$ & $11.2 \pm 0.08$ \\
Protein & $23.2 \pm 0.22$ & $11.6 \pm 0.5$ \\
Fat & $1.2 \pm 0.17$ & $1.4 \pm 0.09$ \\
Crude fiber & $1.8 \pm 0.08$ & $0.78 \pm 0.02$ \\
Ash & $3.1 \pm 0.03$ & $0.7 \pm 0.06$ \\
Carbohydrate & $59.74 \pm 0.09$ & $74.32 \pm 0.03$ \\
\hline
\end{tabular}

${ }^{\text {a }}$ Wet basis. mean \pm standard deviation

\subsection{Proximate composition of bean seed flour biscuits}

The proximate composition of lablab bean seed flour (BSF) biscuits is presented in Table 3. In BSF supplemented biscuits, the moisture content varied from $3.37 \%$ to $4.17 \%$, which were significantly greater $(\mathrm{p} \leq 0.05)$ than control sample (3.01\%). The increased moisture content with the addition of flour protein is in agreement with the study of chickpea flour AND plantains incorporation in biscuits reported by [16]. However, considering prolonging the shelf-life of the products, low moisture content is desirable.

Likewise, moisture, BSF enriched biscuits samples had significantly more protein, crude fiber and ash content than the control sample. The protein content of all treatments with BSF ranges from $9.1 \%$ to $9.92 \%$. These results are in agreement with other studies $[1,17,18]$ where the protein content was observed higher with the replacement of wheat flour. The increase in protein content is satisfactory since the ingestion of protein helps to build-up body mass [19].

The crude fiber content of biscuits increased with increasing BSF substitution level and highest content (2.21\%) found at 20\% and lowest (1.33\%) found at 5\% substitution level. According to Yadav (2012) [16] fiber content of biscuits prepared from plantain, chickpea and wheat composite flour was increased as the proportion of chickpea flour increased. This increase in dietary fiber in biscuits is desirable since it is evident high-fiber diet provides better diges- 
tion and cancer prevention [20].

Concerning ash content, differences were recorded $(\mathrm{p} \leq 0.05)$ among BSF enriched samples and control samples. M. Asif-Ul-Alam (2014) [21] also reported, during green banana flour incorporation in biscuits, control sample showed a lower percentage of ash than the substitution with 5 to $20 \%$ of bean seed flour. The higher ash content in biscuit samples reflects the presence of more mineral content [22].

Table 3. Proximate composition of bean seed flour biscuits

\begin{tabular}{cccccc}
\hline Parameters & Control & \multicolumn{4}{c}{ Biscuit with bean seed powder $(\mathbf{g} / \mathbf{1 0 0} \mathbf{g})$} \\
& $\mathbf{T}_{\mathbf{0}}$ & $\mathrm{T} 1$ & $\mathrm{~T} 2$ & $\mathrm{~T} 3$ & $\mathrm{~T} 4$ \\
\hline Moisture & $3.01 \pm 0.4^{\mathrm{a}}$ & $3.37 \pm 0.13^{\mathrm{b}}$ & $3.78 \pm 0.03^{\mathrm{c}}$ & $3.93 \pm 0.06^{\mathrm{d}}$ & $4.17 \pm 0.1 \mathrm{~d}^{\mathrm{e}}$ \\
Protein & $8.4 \pm 0.23^{\mathrm{a}}$ & $9.1 \pm 0.02^{\mathrm{b}}$ & $9.44 \pm 0.07^{\mathrm{c}}$ & $9.7 \pm 0.1^{\mathrm{d}}$ & $9.92 \pm 0.09^{\mathrm{e}}$ \\
Fat & $20.4 \pm 0.08^{\mathrm{d}}$ & $20.53 \pm 0.12^{\mathrm{d}}$ & $19.62 \pm 0.09^{\mathrm{c}}$ & $18.9 \pm 0.05^{\mathrm{b}}$ & $17.02 \pm 0.38^{\mathrm{a}}$ \\
Crude fiber & $0.95 \pm 0.03^{\mathrm{a}}$ & $1.33 \pm 0.17^{\mathrm{b}}$ & $1.6 \pm 0.03^{\mathrm{c}}$ & $1.93 \pm 0.05^{\mathrm{d}}$ & $2.21 \pm 0.02^{\mathrm{e}}$ \\
Ash & $0.68 \pm 0.01^{\mathrm{a}}$ & $1.2 \pm 0.01^{\mathrm{b}}$ & $1.3 \pm 0.11^{\mathrm{b}}$ & $1.18 \pm 0.07^{\mathrm{b}}$ & $1.5 \pm 0.02^{\mathrm{c}}$ \\
Carbohydrate & $66.56 \pm 0.09$ & 67.2 & 64.26 & 64.36 & 65.18 \\
\hline
\end{tabular}

$\mathrm{T}_{0}=0 \% \mathrm{BSF}$ (control), $\mathrm{T} 1=5 \% \mathrm{BSF}, \mathrm{T} 2=10 \% \mathrm{BSF}, \mathrm{T} 3=15 \% \mathrm{BSF}$, and $\mathrm{T} 4=20 \%$.

The values are the means of triplicate \pm standard deviation. The values of the same superscripts in a row do not vary significantly ( $<<0.05$ ).

The fat content in the biscuits ranged from $17.02 \%$ to $20.4 \%$. The control sample and $\mathrm{T} 1$ (5\%) were equal to each other $(\geq 0.05)$, differing from T2, T3 and T4, where the latter showed the lowest (17.02\%) content and T1 the highest (20.53\%). The reduction in the samples' fat content may be because lablab bean seed flour was found to contain low crude fat values. The obtained results agree with Idowu (2014) [23], where in the biscuit samples, fat content decreased with increasing African yam bean flour. However, in the nutritional point of view low-fat content is more attractive cause it helps to maintain weight loss, cholesterol, cardiovascular diseases, and diabetes [24].

The control sample obtained the highest value (66.56\%) and the lowest was found for composite flour biscuits. The decrease in the BSF enriched samples was possibly due to the variations in other constituents and low carbohydrate content the added bean seed flour [25].

\subsection{Physical properties of bean seed flour biscuits}

The physical properties of biscuits prepared from different bean seed flour are shown in Table 4. The biscuits' diameter and thickness ranged from 4.45-4.75 cm, and 0.52-0.61 cm, respectively. Bean seed flour biscuits $(15 \%$ and $20 \%$ ), showed slightly $(\mathrm{p}<0.05)$ a lower diameter but a greater thickness than $\mathrm{T}_{0}$ (no substitution), $\mathrm{T} 1$ ( $5 \%$ substitution) and T2 (10\% substitution) treatments. This is because more dietary fibers in bean seed flour retain more water than wheat flour and affect the dough's viscosity. When the dough's viscosity increases, the dough expansion during baking decreases, and the maximum diameter also decreases and the hardness of biscuits increases [26]. The diameter and thickness changes were mirrored in the biscuit spread ratio. The highest spread ratio was found for control biscuits 9.03, and lowest 7.37 for $20 \%$ wheat flour substituted biscuit samples. Several studies also found a reduction in the spread ratio when wheat flour substituted with leguminous acha and kidney bean flours [27]. The decline in the spread ratio of BSF biscuits could result from the increasing number of hydrophilic sites available owing to enhanced protein content competing for the limited free water in the dough [28, 29].

Table 4. Physical properties of bean seed flour biscuits

\begin{tabular}{cccccc}
\hline \multirow{2}{*}{ Parameters } & Control & \multicolumn{4}{c}{ Biscuit with bean seed powder (g /100 g) } \\
& $\mathbf{T}_{\mathbf{0}}$ & $\mathrm{T} 1$ & $\mathrm{~T} 2$ & $\mathrm{~T} 3$ & $\mathrm{~T} 4$ \\
\hline Weight & $7.5 \pm 0.02$ & $7.2 \pm 0.1$ & $6.85 \pm 0.32$ & $6.5 \pm 0.09$ & $6.2 \pm 0.03$ \\
Diameter $(\mathrm{cm})$ & $4.7 \pm 0.12$ & $4.75 \pm 0.03$ & $4.63 \pm 0.1$ & $4.5 \pm 0.04$ & $4.45 \pm 0.02$ \\
Thickness (cm) & $0.52 \pm 0.01$ & $0.55 \pm 0.07$ & $0.56 \pm 0.02$ & $0.58 \pm 0.12$ & $0.61 \pm 0.04$ \\
Spread ratio & 9.03 & 8.63 & 8.26 & 7.84 & 7.37 \\
\hline
\end{tabular}

$\mathrm{T}_{0}=0 \% \mathrm{BSF}$ (control), $\mathrm{T} 1=5 \% \mathrm{BSF}, \mathrm{T} 2=10 \% \mathrm{BSF}, \mathrm{T} 3=15 \% \mathrm{BSF}$, and $\mathrm{T} 4=20 \%$.

The values are the means of triplicate \pm standard deviation. 


\subsection{Sensory characteristics of bean seed flour biscuits}

The effects of incorporating bean-seed flour on biscuits' sensory properties are shown in Table 5. As the amount of bean seed flour increased in the formulation, the sensory values for color, flavor, taste, texture and overall acceptance of biscuits get decreased.

Table 5. Sensory scores of bean seed flour biscuits

\begin{tabular}{|c|c|c|c|c|c|}
\hline \multirow{2}{*}{ Samples } & \multicolumn{5}{|c|}{ Attributes } \\
\hline & Color & Flavor & Texture & Taste & Overall acceptability \\
\hline $\mathrm{T}_{0}$ & $7.1 \pm 0.2^{c}$ & $7.5 \pm 0.05^{\mathrm{b}}$ & $7.4 \pm 0.14^{\mathrm{c}}$ & $7.5 \pm 0.06^{b}$ & $7.4 \pm 0.12^{b}$ \\
\hline $\mathrm{T} 1$ & $6.8 \pm 0.18^{c}$ & $7.3 \pm 0.25^{\mathrm{b}}$ & $7.3 \pm 0.11^{\mathrm{c}}$ & $7.5 \pm 0.15^{\mathrm{b}}$ & $7.3 \pm 0.18^{\mathrm{b}}$ \\
\hline $\mathrm{T} 2$ & $7.2 \pm 0.3^{c}$ & $7.3 \pm 0.19^{b}$ & $6.9 \pm 0.41^{\mathrm{c}}$ & $7.2 \pm 0.31^{b}$ & $7.2 \pm 0.3^{\mathrm{b}}$ \\
\hline T3 & $6.5 \pm 0.2^{\mathrm{b}}$ & $6.2 \pm 0.34^{\mathrm{a}}$ & $6.5 \pm 0.21^{b c}$ & $5.8 \pm 0.21^{\mathrm{a}}$ & $6.2 \pm 0.23^{\mathrm{a}}$ \\
\hline $\mathrm{T} 4$ & $6.0 \pm 0.15^{\mathrm{a}}$ & $6.3 \pm 0.14^{\mathrm{a}}$ & $5.9 \pm 0.32^{\mathrm{a}}$ & $5.9 \pm 0.11^{\mathrm{a}}$ & $6.1 \pm 0.11^{\mathrm{a}}$ \\
\hline
\end{tabular}

$\mathrm{T}_{0}=0 \% \mathrm{BSF}$ (control), $\mathrm{T} 1=5 \% \mathrm{BSF}, \mathrm{T} 2=10 \% \mathrm{BSF}, \mathrm{T} 3=15 \% \mathrm{BSF}$, and $\mathrm{T} 4=20 \%$.

The values of the same superscripts in a row do not vary significantly $(\mathrm{p}<0.05)$.

Among five types of biscuits, wheat flour replaced with $5 \%$ and $10 \%$ bean seed flour were ranked in the same group with control and had similar color, flavor, texture, taste and overall acceptance. However, incorporating the seed flour level above $15 \%$ significantly decreased $(p<0.05$ ) the sensory scores. The substitution of wheat flours up to $10 \%$ bean seed flour provides protein-enriched biscuits with a reasonable acceptability.

\section{Conclusion}

This study has demonstrated that, lablab bean seed flour with a high protein, ash and dietary fiber, and a low fat and carbohydrate content is appraised a suitable ingredient to substitute wheat flour in baked items. Biscuits made with combined wheat/label bean seed flour had a high protein, dietary fiber and ash content and a low fat and carbohydrate content with statistical distinctions ( $\mathrm{p} \leq 0.05$ ) as compared to bisc uits with wheat flour only. The reasonable sensory properties (color, flavor, texture, taste and acceptability) may allow the processing of such products and can be served as an alternative use of lablab bean seed flour to benefit from their nutritional and functional qualities. Lablab bean seed has the potential to increase food security and nutrition in developing countries like Bangladesh. Additional monitoring of nutrients and antioxidants' digestibility may be a beneficial method when promoting seeds as a foodstuff.

\section{Acknowledgment}

The authors express their gratitude to the Department of Food Engineering and Tea Technology, Shahjalal University of Science and Technology for continuous materials support and technical assistance.

\section{Conflicts of interest}

The authors declare no competing interests exist.

\section{References}

[1] Amalfitano, C., Agrelli, D., Borrelli, C., Cuciniello, A., Morano, G., \& Caruso, G. (2018). Production system effects on growth, pod yield and seed quality of organic faba bean in southern Italy. Folia Horticulturae, 30(2), 375-385. https://doi.org/10.2478/fhort-2018-0033.

[2] Okaka, J. C., Okoye, J. I., \& Onuora, J. O. (2009). Biscuit making, functional, sensory and nutritional properties of high legume protein wheat flour-raw, cooked and toasted brown bean (phaseolus vulgaris). J. Sci. Technol., 15: 61, 77.

[3] Venkatachalam, M., \& Sathe, S. K. (2007). Val bean (Lablab purpureus L) proteins: Composition and biochemical properties. Journal of the Science of Food and Agriculture, 87(8), 1539-1549. https://doi.org/10.1002/jsfa.2885.

[4] Kalloo, G., \& Pandey, S. C. (1993). Hyacinth bean. In Genetic Improvement of Vegetable Crops. Elsevier. https://doi.org/10.1016/B978-0-08-040826-2.50030-8.

[5] Habib, H. M., Theuri, S. W., Kheadr, E. E., \& Mohamed, F. E. (2017). Functional, bioactive, biochemical, and physicochemical properties of the Dolichos lablab bean. Food and Function, 8(2), 872-880. https://doi.org/10.1039/c6fo01162d.

[6] Deka, R. K., \& Sarkar, C. R. (1990). Nutrient composition and antinutritional factors of Dolichos lablab L. seeds. Food Chemistry, 38(4), 239-246. https://doi.org/10.1016/0308-8146(90)90180-c. 
[7] Khalil, M. M. (2001). Effect of soaking, germination, autoclaving and cooking on chemical and biological value of guar compared with faba bean. Food/Nahrung, 45(4), 246-250. https://doi.org/10.1002/1521-3803(20010801)45:4\% 3C246::aid-food246\%3E3.0.co;2-f.

[8] Siddiq, M., \&Uebersax, M. A. (2013). Dry beans and pulses production, processing, and nutrition. Wiley Online Library.

[9] Gupta, S., Chhabra, G. S., Liu, C., Bakshi, J. S., \& Sathe, S. K. (2018). Functional Properties of Select Dry Bean Seeds and Flours. Journal of Food Science, 83(8), 2052-2061. https://doi.org/10.1111/1750-3841.14213.

[10] Maia, L. C., Nano, R. M. W., Santos, W. P. C., Nascimento, P. V. B. S. do, Miranda, K. E. de S., \& Oliveira, F. S. de. (2020). Mineral profile and characterisation of cookies made from legume green grain flour. Food Science and Technology. https://doi.org/10.1590/fst.22020.

[11] Arepally, D., Reddy, R. S., Goswami, T. K., \& Datta, A. K. (2020). Biscuit baking: A review. In LWT (Vol. 131). Academic Press. https://doi.org/10.1016/j.lwt.2020.109726.

[12] AACC, C. (2000). Approved methods of the American association of cereal chemists. Methods, 54, 21.

[13] AOAC. (2010). Official Methods of Analysis of Association of Official Analytical Chemists. 18th Edition, Washington, DC.

[14] Hossain, S., Ahmed, R., Bhowmick, S., Mamun, A. al, \& Hashimoto, M. (2016). Proximate composition and fatty acid analysis of Lablab purpureus (L.) legume seed: implicates to both protein and essential fatty acid supplementation. SpringerPlus, 5(1). https://doi.org/10.1186/s40064-016-3587-1.

[15] Yadav, R. B., Yadav, B. S., \& Dhull, N. (2012). Effect of incorporation of plantain and chickpea flours on the quality characteristics of biscuits. Journal of Food Science and Technology, 49(2), 207-213. https://doi.org/10.1007/s13197-011-0271-X.

[16] Rahman, T., Akter, S., Sabuz, A. A., \& Rana, R. (2021). Characterization of Wheat Flour Bread Fortified with Banana Flour. International Journal of Food Science and Agriculture, 5(1), 7-11. https://doi.org/10.26855/ijfsa.2021.03.002.

[17] Simanca-Sotelo, M., de Paula, C., Domínguez-Anaya, Y., Pastrana-Puche, Y., \& Álvarez-Badel, B. (2021). Physico-chemical and sensory characterization of sweet biscuits made with Yacon flour (Smallanthussonchifolius). NFS Journal, 22, 14-19. https://doi.org/10.1016/j.nfs.2020.12.001.

[18] Farzana, T., \& Mohajan, S. (2015). Effect of incorporation of soy flour to wheat flour on nutritional and sensory quality of biscuits fortified with mushroom. Food Science and Nutrition, 3(5), 363-369. https://doi.org/10.1002/fsn3.228.

[19] Carbone, J. W., \& Pasiakos, S. M. (2019). Dietary protein and muscle mass: Translating science to application and health benefit. Nutrients, 11(5), 1136. https://doi.org/10.3390/nu11051136.

[20] Prasad, K. N., \&Bondy, S. C. (2019). Dietary fibers and their fermented short-chain fatty acids in prevention of human diseases. Bioactive Carbohydrates and Dietary Fibre, 17, 100170. https://doi.org/10.1016/j.bcdf.2018.09.001.

[21] M. Asif-Ul-Alam, S., Z. Islam, M., M. Hoque, M., \& Monalisa, K. (2014). Effects of Drying on the Physicochemical and Functional Properties of Green Banana (Musa sapientum) Flour and Development of Baked Product. American Journal of Food Science and Technology, 2(4), 128-133. https://doi.org/10.12691/ajfst-2-4-4.

[22] Cecchi, H. M. (2003). Fundamentosteóricos e práticosemanálise de alimentos. Editora da UNICAMP. https://doi.org/10.7476/9788526814721.0001.

[23] Idowu, A. (2014). Development, Nutrient Composition and Sensory Properties of Biscuits Produced from Composite Flour of Wheat and African Yam Bean. British Journal of Applied Science \& Technology, 4(13), 1925-1933. https://doi.org/10.9734/bjast/2014/7183.

[24] Aggarwal, M., Bozkurt, B., Panjrath, G., Aggarwal, B., Ostfeld, R. J., Barnard, N. D., Gaggin, H., Freeman, A. M., Allen, K., \& Madan, S. (2018). Lifestyle modifications for preventing and treating heart failure. Journal of the American College of Cardiology, 72(19), 2391-2405. https://doi.org/10.1016/j.jacc.2018.08.2160.

[25] Milkesa, F. (2020). Review on some cereal and legume based composite biscuits. International Journal of Agricultural Science and Food Technology, 101-109. https://doi.org/10.17352/2455-815x.000062.

[26] Canalis, M. S. B., León, A. E., \& Ribotta, P. D. (2017). Effect of inulin on dough and biscuit quality produced from different flours. International Journal of Food Studies, 6(1), 13-23. https://doi.org/10.7455/ijfs/6.1.2017.a2.

[27] Inyang, U. E., Daniel, E. A., \& Bello, F. A. (2018). Production and Quality Evaluation of Functional Biscuits from Whole Wheat Flour Supplemented with Acha (Fonio) and Kidney Bean Flours. Asian Journal of Agriculture and Food Sciences, 6(6). https://doi.org/10.24203/ajafs.v6i6.5573.

[28] Tiwari, B. K., Brennan, C. S., Jaganmohan, R., Surabi, A., \& Alagusundaram, K. (2011). Utilisation of pigeon pea (Cajanus cajan L) byproducts in biscuit manufacture. LWT-Food Science and Technology, 44(6), 1533-1537. https://doi.org/10.1016/j.lwt.2011.01.018.

[29] Zucco, F., Borsuk, Y., \& Arntfield, S. D. (2011). Physical and nutritional evaluation of wheat cookies supplemented with pulse flours of different particle sizes. LWT-Food Science and Technology, 44(10), 2070-2076. https://doi.org/10.1016/j.lwt.2011.06.007. 